\title{
ANALISIS MPN (Most Probable Number) COLIFROM PADA ES PUTER YANG BEREDAR DI KABUPATEN GOWA DAN MAKASSAR
}

\author{
Mursalim $^{1}$, Sitti hadijah ${ }^{2}$, Hasnawati ${ }^{3}$ \\ 1,2,3 Jurusan Analis Kesehatan Poltekkes Makassar \\ Koresponden : liemachmad@gmail.com
}

\begin{abstract}
ABSTRAK
Es Puter adalah minuman Es yang terbuat dari santan kelapa dan pada prosespembuatannya cukup lama yang dapat menyebabkan coliform dapat tumbuh atau mencemari es putar tersebut. Tujuan penelitian ini adalah untuk mengetahui jumlah MPN coli pada es puter yang dijual di Kabupatn Gowa dan Makassar. Jenis penelitian ini adalah observasional laboratorik yang bersifat deskriptif. Jumlah sampel sebanyak 15 sampel yang diperolah dengan menggunakan accidental sampling. Penelitian ini dianalisa dilaksanakan di laboratorium Bakteriologi Jurusan Analis Kesehatan Poltekkes Kemenkes Makassar pada tanggal 9 sampail3 Agustus 2018. Dari hasil penelitian yang telah dilakukan didapat MPN coliform yaitu 96 - 240 kuman/ 100ml sampel, sehingga dapat disimpulkan bahwa dari 15 sampel es puter semua positif mengandung coliform dan tidak layak dikonsumsi, karena tidak sesuai dengan Permenkes No 492/Menkes/per/IV/2010 tentang kualitas mikrobiologis air yaitu 0/100ml dan 3 MPN/100ml Dan disarankan perlu dilakukan pemeriksaan lanjutan dengan pemeriksaan coli tinja dan identifikasi bakteri patogen.
\end{abstract}

Kata kunci : MPN, Coliform, Es Puter

\section{PENDAHULUAN}

Es puter merupakan salah satu jenis dari prodak es krim yang dikembangkan oleh masyarakat lokal. Es puter lahir dari kreasi masyarakat Indonesia yang menggantikan bahan utama yaitu susu sapi diganti dengan santan kelapa yang lebih mudah didapat serta harganya lebih murah. Dengan memadukan santan kelapa dengan buah-buahan lokal seperti kelapa muda, nangka, atau durian terciptalah sejenis es krim yang kita kenal dengan sebutan es puter (Prihatini, 2008). Faktor yang berperan dalam pencemaran bakteri coliform fekal berdasarkan hasil observasi pedagang es puter adalah cara pembuatannya, serta penyimpanan es krim.

Menurut badan POM RI Nomor HK 00.06.1.52.401 Tahun 2009 batas maksimum pencemaran bakteri koliform fekal pada es krim adalah 3 MPN $/ \mathrm{ml}$, sehingga jika pada es puter diketahui pencemaran melebihi batas tersebut maka dinyatakan tidak layak konsumsi. (BPOM, 2009).

Menurut data yang diperoleh pada Dinas Kesehatan Kotamadya Makassar bahwa infeksi bakteri dan sakit perut. Kasus diare yang ditemukan dan ditangani yang 
dilaporkan oleh 46 puskesmas se Kota Makassar sampai dengan desember 2015 sebanyak 28.257 kasus dengan Angka Kesakitan (Incidence Rate/IR) yaitu 20,07 per 1.000 penduduk meningkat dari tahun 2014 yaitu 26.485

kasus dengan Angka Kesakitan (Incidence Rate/IR) yaitu 19,34 per 1.000 penduduk,

Indikasi golongan bakteri coliform fekal yaitu Escherichia coli adalah bakteri yang umum dan hidup dalam usus manusia maupun hewan atau lebih dikenal dengan istilah intestinal. Sebagian besar keberadaan bakteri ini tidak merugikan bagi pencernaan. Namun ada beberapa kondisi sehingga dapat menimbulkan berbagai macam gangguan pencernaan, seperti terlalu banyak jumlah bakteri dalam usus sehingga menyebabkan infeksi saluran pencernaan.

Escherichia coli yang terdapat pada makanan atau minuman yang masuk kedalam tubuh manusia dapat menyebabkan gejala seperti kolera,disentri,gastroenteritis,

diare, dan berbagai penyakit saluran pencernaan lain.

Escherichia coli merupakan kuman berbentuk batang pendek (koko basil) Gram negatif, ukuran $0,4-0,7 \mu \mathrm{m}$ $\mathrm{X} 1,4 \mu \mathrm{m}$, sebagian gerak positif dan beberapa strain mempunyai kapsul. Escherichia coli tumbuh baik pada hampir semua media yang biasa dipakai di laboratorium mikrobiologi pada media yang dipergunakan untuk isolasi kuman enterik. Sebagian besar strain Escherichia coli tumbuh sebagai koloni yang meragi laktosa Escherichia coli bersifat mikroaerofilik. Beberapa strain bila ditanam pada agar darah menunjukkan hemolisis tipe beta (Karsinah, 1994). Koloni yang berwarna merah pada agar Mac Conkey menunjukkan bahwa basil memfermentasi laktosa dan bersifat non patogen di dalam intestin (Gibson, 1996).

Ada dua macam enterotoksin yang diisolasi dari Eschrichia coli yaitu:

\section{Termolabil Toksin (LT)}

Seperti toksin kolera, toksin LT bekerja merangsang enzim adenil siklase yang terdapat didalam sel epitel mukosa usus halus menyebabkan peningkatan aktivitas enzim tersebut dan terjadinya peningkatan permeabilitas sel epitel usus, sehingga terjadi akumulasi cairan dalam usus dan berakhir dengan diare. Toksin LT seperti juga toksin kolera bersifat cytopathis terhadap sel tumor adrenal dan sel ovarium Chinese hamster serta meningkatkan permeabilitas kapiler pada test rabit skin. Kekuatan toksin LT adalah 100x lebih rendah dbandingkan toksin kolera dalam menimbulkan diare.

\section{Termostabil Toksin (ST)}

Toksin ST adalah asam amino dengan berat molekul 1970 dalton, mempunyai satu atau lebih ikatan disulfda yang penting untuk mengatur stabilitas $\mathrm{pH} 7$ dan suhu $37^{\circ} \mathrm{C}$. Produksi kedua jenis toksin ini diatur oleh plasmid yang mampu pindah dari satu sel kuman ke sel kuman lainnya yaitu 1 plasmin lainnya mengatur pembentukan toksin ST saja.

Sehubungan dengan infeksi pada usus dikenal lima jenis Escherichia coli, yaitu:

1. Enteropathogenik Escherichia coli (EPEC) 
Penyebab penting diare pada bayi, khususnya di Negara berkembang. EPEC melekat pada sel mukosa yang kecil. Faktor yang diperantarai secara kromosom menimbulkan pelekatan yang kuat. Akibat dari infeksi EPEC adalah diare cair yang biasanya sembuh sendiri taetapi dapat juga kronik. EPEC menyebabkan diare pada bayi atau anak - anak kurang dari 1 tahun dan jarang pada orang dewasa dengan gejala berupa demam tidak tinggi, muntah, malaise dan diare.

2. Enterotoxigenik Escherichia coli (ETEC)

Penyebab yang sering dari "diare wisatawan" dan sangat penting menyebabkan diare pada bayi di Negara berkembang. Faktor kolonisasi ETEC yang spesifik untuk menimbulkan pelekatan ETEC pada sel epitel usus kecil. Lumen usus terengang oleh cairan dan Mengakibatkan hipermortilitas serta diare, dan berlangsung selama beberapa hari.

3. Enteroinvasive Escherichia coli (EIEC)

EIEC menyebabkan diare mirip dengan yang disebabkan oleh shigella, baik pada anak - anak maupun orang dewasa. Tinja agak encer bahkan seperti air, mengandung nanah, lender dan darah dengan gejala panas dan malaise.

\section{Enterohemorrhagic Escherichia coli} (EHEC)

EHEC dikenal sebagai penyebab diare hemorhagik dan colitis serta hemolytic uremic syndrome (HUS) yang ditandai dengan jumlah trombosit berkurang, anemia hemolitik dan kegagalan ginjal. Tinja encer berair, mengandung darah dan abdomen terasa sakit, kram serta demam rendah atau tanpa demam.

5. Enterodherant Escherichia coli (EAEC)

Menyebabkan diare akut dan kronik pada masyarakat di Negara berkembang. EAEC menproduksi hemolisin dan ST enterotoksin yang sama dengan ETEC. EAEC menyebabkan diare dengan cara menempel kuat pada permukaan mukosa usus dengan gejala tinja encer berair, muntah, dehidrasi, dan biasanya sakit pada abdomen. (Gaani A, 2003).

Dari uraian diatas peneliti telah melakukan penelitian analisis mpn (most probable number) colifrom pada es puter yang beredar di Kabupaten Gowa dan Makassar

\section{METODE}

Jenis penelitian yang dilakukan adalah observasi laboratorik yang bersifat deskriptif untuk mengetahui jumlah MPN coli pada es puter yang beredar di Kabupaten Gowa dan Makassar.

Sampel yang digunakan dalam penelitian ini adalah sebanyak 15 es puter yang diambil dengan menggunakan tehnik pengambilan sampel yaitu accidental sampling.

Instrumentasi Penelitian

Instrumentasi penelitian yaitu berupa alat - alat yang digunakan untuk pengumpulan data, dokumentasi, izin penelitian, kotak sampling,

Prosedur Penelitian

1. Metode yang digunakan dalam penelitian ini adalah pemeriksaan laboratorium dengan penentuan 
jumlah bakteri metode Most Probable Number (MPN) coliform atau perkiraan jumlah kuman terdekat dengan memakai porsi 5-11 .

2. Prinsip:

Coliform memfermentasikan laktosa yang ditandai dengan terbentuknya gas pada media LB (Lactosa Broth) dan BGLB (Brilliant Green Bile Lactosa Broth). Nilai most probable number (MPN) dihitung berdasarkan jumlah tabung yang positif yang disesuaikan dengan nilai tabel Most Probable Number (MPN).

3. Persiapan Alat dan Bahan

a Alat: Box sampel, cup sampling, tabung reaksi steril, erlenmeyer $250 \mathrm{ml}$, beaker glass, tabung durham, autoclave, sendok/tangkai pengaduk, rak tabung, pipet ukur (10 $\mathrm{ml}$ dan $1 \mathrm{ml})$, pipet tetes, bunsen, timbangan, oven, inkubator, ose bulat, tali pengikat, kertas pembungkus, korek api, label, pulpen, kapas dan cool box.

b Bahan: Sampel es puter, alkohol $70 \%$, aquades, media LB (Lactosa Broth) 1,5\% dan 0,5\%, media BGLB (Brilliant Green Bile Lactosa Broth), E.C Bronth, Endo Agar/ EMBA ( Eosin Methylen Blue Agar), TSIA, dan IMVIC (Indol, Methylen Red- Voges Proskauer, dan Simon's Citrat).

\section{Cara kerja}

Tes pendahuluan

Disiapkan satu seri tabung uji (seri 511) lalu diberi label : lima tabung berisi LB konsentrasi 1,5\% sebanyak $10 \mathrm{ml}$ sampel Es puter, satu tabung berisi LB konsentrasi $0,5 \%$ sebanyak 1 ml sampel Es puter dan satu tabung berisi LB konsentrasi $0,5 \%$ sebanyak $0,1 \mathrm{ml}$ sampel Es puter. Lalu dihomogenkan sampel Es puter dengan dikocok kuat setelah itu mulut botol disterilkan dengan melewatkan mulut botol pada nyala api spiritus. Kemudian dipindahkan $10 \mathrm{ml}$ sampel Es puter kedalam lima tabung yang berlabel LB konsentrasi 1,5\% dengan menggunakan pipet $10 \mathrm{ml}$. Lalu dipindahkan $1 \mathrm{ml}$ sampel Es puter kedalam lima tabung yang berlabel LB konsentrasi 0,5\% dengan menggunakan pipet $1 \mathrm{ml}$. Dan terakhir dipindahkan 0,1 $\mathrm{ml}$ sampel Es puter kedalam lima tabung yang berlabel LB konsentrasi $0,5 \%$ dengan menggunakan pipet $1 \mathrm{ml}$. kemudian menginkubasi selama 18-24 jam pada suhu $37^{\circ} \mathrm{C}$, jika belum ada pertumbuhan (kekeruhan dan terdapat gas dalam tabung durham) maka inkubasi dilanjutkan sampai 48 jam lalu diamati semua tabung LB (Lactosa Broth) yang memperlihatkan kekeruhan dan terbentuknya gas dalam tabung durham.

Tes penegasan BGLB

Tabung yang positif selanjutnya dipindahkan 1-2 ose ke dalam tabung yang berisi media BGLB lalu diinkubasi pada suhu $37^{\circ} \mathrm{C}$ selama 24 jam. Diamati tabung positif pada media BGLB yang ditandai dengan terbentuknya kekeruhan dan gas dalam tabung durham. Dan dipindahkan 1-2 ose ke dalam tabung yang media E.C. Broth pada suhu $44^{\circ} \mathrm{C}$ selama 24 jam. Diamati tabung positif pada media E.C. Broth yang ditandai dengan 
terbentuknya kekeruhan dan gas dalam tabung durham.

Tes penentuan jenis bakteri Dimana tes ini melakukan isolasi dan identifikasi tehadap es puter dimana ingin mengetahui apakan bakteri ini merupakan bakteri coliform fekal atau bukan menggunakan media sesuai prosedur kerja yang berlaku di BPOM.

\section{HASIL}

Dari penelitian yang telah dilakukan pada 15 sampel es puter diperoleh hasil sebagai berikut.

Tabel. 1 Hasil Pemeriksaan Sampel dengan Jumlah MPN coli

\begin{tabular}{cc}
\hline $\begin{array}{c}\text { Kode } \\
\text { Sampel }\end{array}$ & Jumlah MPN coli \\
\hline $\mathbf{1}$ & 96 \\
\hline $\mathbf{2}$ & 240 \\
\hline $\mathbf{3}$ & 240 \\
\hline $\mathbf{4}$ & 240 \\
\hline $\mathbf{5}$ & 96 \\
\hline $\mathbf{6}$ & 240 \\
\hline $\mathbf{7}$ & 96 \\
\hline $\mathbf{8}$ & 96 \\
\hline $\mathbf{9}$ & 240 \\
\hline $\mathbf{1 0}$ & 240 \\
\hline $\mathbf{1 1}$ & 96 \\
\hline $\mathbf{1 2}$ & 96 \\
\hline $\mathbf{1 3}$ & 240 \\
\hline $\mathbf{1 4}$ & 240 \\
\hline $\mathbf{1 5}$ & 240 \\
\hline
\end{tabular}

1. Hasil pemeriksaan pada media LB (Lactose Broth) semua positif $(+)$.

2. Hasil pemeriksaan Colifrom pada media BGLB (Brilliant Green Bile lactose Broth) didapatkan 96 - $240 \mathrm{MPN} / 100 \mathrm{ml}$.

\section{PEMBAHASAN}

Pada penelitian ini dilakukan pemeriksaan es puter yang bertujuan untuk mengetahui kualitas es puter tersebut layak dikomsumsi oleh masyarakat atau tidak. Diketahui bahwa es puter merupakan minuman es yang sangat digemari oleh masyarakat sekitar umumnya rakyat dibawa standar. Dimana es puter ini terbuat dari santan kelapa dan proses pembuatannya cukup lama. Bahan baku dalam pembuatan jajanan tersebut dapat tercemar mulai dari proses pembuatan, tidak terkecuali es puter yang berbahan dasar santan kelapa. (Risbawan, 1999). 
Dalam penelitian ini peneliti menggunakan kontrol media negative dengan perlakuan tanpa menggunakan sampel. Tujuan digunakannya control media negatif yaitu untuk memastikan hasil penelitian yang positif tercemar bakteri Coliform dan Coli tinja itu benar-benar berasal dari sampel bukan dari media atau cara pengerjaannya. Berdasarkan hasil penelitian dari 15 sampel tersebut dinyatakan MPN coli positif dengan jumlah diatas ambang batas yaitu antara 96 - 240 kuman/100 ml sampel, sehingga dapat dipastikan bahwa semua sampel yang diambil secara acak tidak layak untuk dikonsumsi.

Standar baku mutu Menteri Kesehatan Republik Indonesia Nomor 492 Tahun 2010 Tentang Persyaratan Kualitas Air Minum, bahwa air untuk minum seharusnya tidak mengandung bakteri patogen dan kadar maksimum Escherichia coli pada air minum adalah 0/100 mL sampel. Dan menurut badan POM RI Nomor HK 00.06.1.52.401 Tahun 2009 batas maksimum pencemaran bakteri koliform fekal pada es krim adalah $3 \mathrm{MPN} / \mathrm{ml}$, sehingga jika pada es puter diketahui pencemaran melebihi batas tersebut maka dinyatakan tidak layak konsumsi

\section{KESIMPULAN}

Dari hasil pemeriksaan laboratorium terhadap 15 sampel es puter didapatkan 96-240 kuman/100ml sampel (semua positif) mengandung coliform

\section{SARAN}

1. Untuk peneliti selanjutnya Agar dilakukan pemeriksaan lanjutan yaitu pemeriksaan coli tinja dan identifikasi bakteri pathogen

2. Kepada Masyarakat agar berhati hati mengkonsumsi es puter yang dijual di pinggir jalan.

\section{UCAPAN TERIMA KASIH}

Kepada yang terhormat :

1. Direktur Poltekkes Kemenkes Makassar yang telah memberikan izin dalam penelitian ini.

2. Ketua Jurusan Analis Kesehatan Poltekkes Makassar yang telah memberikan support dan izin untuk melaksanakan penelitian.

3. Kepada Seluruh teman teman yang telah berpartisipasi dan membantu dalam penelitian ini.

\section{DAFTAR PUSTAKA}

BPOM RI. 2009. Pengujian Mikrobiologi Pangan. Jurnal. Infopom Badan Pengawas Obat Dan Makanan Republik Indonesia. Vol. 9, No. 2.

Gaani A. 2003. Pengantar Mikrobiologi Umum. Angkasa, Bandung.

Gibson. 1996. Bakteri Koliform yang Bersifat Anaerob. Diperoleh:www.1Sthumanwinner. com/2010/12/16?bakteri-

koliform- yang bersifatanaerob [Diakses tanggal 20 Maret 2018].

Prihartini, R.I. 2008. Analisa Kecukupan Panas pada Proses Pasteurisasi Santan. Naskah Skripsi S-1. Fakultas Teknologi Pertanian Institut Pertanian Bogor, Bogor. 
Jurnal Me dia Anal is Ke sehatan, Vol. 9, No.2, November 2018 http://journal .poltekkes-mks.ac.id/ojs2/index.php/mediaanalis e-ISSN : 2621-9557 p-ISSN : 2087-1333

Rimbawan, 1999, Mutu Mikrobiologis

Minuman Jajanan di Sekolah

Dasar

Bogor
Tengah.Jurnal Gizi dan Pangan. 1(1): 44-50. 